\title{
TOLERANCE VALUES REPRESENTATION IN INDONESIA ELECTRONIC EFL TEXTBOOKS
}

\author{
Nuryansyah Adijaya \\ Fakultas Keguruan dan Ilmu Pendidikan, Universitas Esa Unggul, Jakarta \\ Corresponding Email: nuryansyah@esaunggul.ac.id
}

Received: 7th of July 2020, Accepted: $1^{\text {st }}$ of December 2020, Published: $10^{\text {th }}$ of December 2020

\begin{abstract}
Teaching students tolerance values play an important role to give them knowledge about how to live together in harmony, respect others, avoid potential conflicts and so on. This study is aimed at analyzing tolerance values representation in the $1^{\text {st }}$ grade of Junior High School EFL Textbook published by Indonesian Ministry for Education and Culture (Kemendikbud). There are 4 kinds of tolerance values were analyzed; peace maker, cultural diversity, democracy and religious values. Qualitative content analysis was used to analyze tolerance values representation in the texts, illustrations, instructions, and exercises of the textbooks. The research shows that the textbook covers 72 tolerance values; 24 peace maker, 19 cultural diversity, 15 democracy, and 14 religious values. However, the textbook needs deeper exploration about the values to help students get vivid points of view about tolerance by giving them more real-life samples, and discussions.
\end{abstract}

Keywords:tolerance values, EFL electronic textbook, learning-teaching process

\begin{abstract}
Abstrak
Mengajarkan para siswa nilai-nilai toleransi memiliki peranan penting untuk memberikan mereka pengetahuan tentang bagaimana untuk hidup bersama dalam keharmonisan, memghormati orang lain, menghindarkan potensi konflik, dan sebagainya. Penelitiann ini bertujuan untuk menganalisis representasi nilai-nilai toleransi dalam buku teks bahasa Inggris untuk kelas 1 sekolah menengah pertama yang dipublikasi oleh kementerian pendidikan dan kebudayaan republik Indonesia (Kemdikbud). Ada 4 jenis nilai-nilai toleransi yang dianalisis; pencipta kedamaian, keragaman budaya, demokrasi, dan nilai-nilai relijius. Kualitatif konten analisis digunakan untuk menganalisis nilai-nilai tersebut yag terkandung di dalam teks-teks, ilustrasiilustrasi, instruksi-instruksi and latihan-latihan dari buku teks tersbut. Penelitian ini menemukan bahwa ada 72 nilai-nilai toleransi yang terbagi kedalam; 24 item nilai penjaga kedamaian, 19 item nilai keberagaman budaya, 15 item nilai demokrasi, dan 14 item nilai relijius. Namun, buku teks tersebut perlu mengekplorasi lebih dalam tentang nilai-nilai tersebut untuk membantu para siswa mendapatkan cara pandang yang jelas tentang toleransi dengan memberikan mereka lebih banyak contoh dari kehidupan nyata dan diskusi-diskusi.
\end{abstract}

Kata kunci:: nilai-nilai toleransi, buku text EFL elektronik, proses belajarmengajar

Copyright $@ 2020$ Nuryansyah Adijaya

\section{INTRODUCTION}

Nowadays, we often watch on television or listen to radio many conflicts happen in almost every place in the world. Many factors cause the conflicts. One of the factors that causes a 
conflict is the different point of view which adopted by people in life such as beliefs, cultures, norms and so on. So, what should we do to avoid the conflict? We may think that is very simple to answer it. We just need to respect other people and live together in harmony. However, it is not as easy as we think. We have to work hard to realize it. We often find group of people that live in certain area fight each other. They burn house of worship. they insult one another. they do unnecessary thing that can cause a conflict. We do not know what for they do that? Why does the conflict happen? It shows that they cannot respect the differences. They do not have self awareness to make harmony in life. They lack of tolerance. (Dobbernack \& Modood, 2011) and (Yusuf, 2013) define tolerance as self awareness to respect other people in order to create harmony in life. From the definition, we can infer that tolerance is an important value to create harmony in life by loving and respecting other people. Along with the importance of tolerance in life, we should plant and grow it especially for children. It should be introduced to very young age persons in order to prepare them with very important values in life. But in fact, it is not easy to do it. It needs long process. It needs supports from many parties; government, family, environment, educational institutions, and so on.

Educational institution, especially school has an important role and responsibility to plant and grow people' s tolerance especially for children by giving them information, samples, and discussions which can boost their tolerance values. Therefore, planting and growing tolerance should be seen as an integrated system or process in learning-teaching activities. (Kurniawan, 2018) stated that learning process has a great opportunity to enhance students' tolerance by giving them understanding toward different point of view in life. Meanwhile, (Suardi Wekke, 2017) said that learning process must be able to give positive attitudes about multicultural conditions and reduce social conflicts.

Now, the questions arise what values should be taught to enhance tolerance values and how to integrate them in learning teaching process? (Hameiri, Bar-Tal, \& Halperin, 2014) (Giuliani et al., 2004) and (Abdul Rahman \& Mohd Khambali, 2013) said that there are at least four values should be embedded in learning teaching process; peace maker, cultural diversity, democracy and religious values. Peace value is awareness and spirit to keep good relationships and avoid conflicts or even reconcile dispute among people. There are peace values can be taught such as conflict prevention, conflict reconciliation, and so on. For example a teacher gives sample of two students who have conflict.Then, the teacher asks his students what can you do to reconcile the situation? Cultural diversity is a value of understanding the differences of people's culture; behaviors,norms, ethics, and so on. The values can be discussed to improve students' cultural awareness. Democracy value is a freedom to choose and express mind without intimidation, 
participation in doing something, etc. Some democracy values can be discussed in learning process such as voting candidates, expressing mind in taking decision, and so on. For example: two best friends who have different vote for captain of the class candidates and they are free to vote one of them without intimidating. Religious value is every single action or thought which is based on God. The values can be taught such as kindness, honesty, worship, and so on. For example, teachers can discuss certain religion in order that students understand and respect its followers. Along with the importance of the values above, it needs to involve them in learning teaching process in order to plant and grow students tolerance in their life. (Leo, 2010) expressed that learning teaching process is not only addressed to make students get knowledge but also it must be able to boost their tolerance values. There are several ways to integrate the values in learning teaching process. One of them is by representing the values into learning materials including English for foreign language (EFL) textbooks. However, in real situation EFL materials do not give equal portion both language knowledge and values of tolerance. This situation inspires the researcher to explore the representation of tolerance values in EFL textbooks. Three research questions are addressed in this research; how many tolerance values covered in Indonesian EFL electronic textbook for the first grade of Jenior high school?, How are tolerance values represented in Indonesian EFL textbooks?, And what is the dominant tolerance values represented in the textbook?

\section{Tolerance in EFL Learning and Teaching Process}

Boosting students' tolerance values become an important part in learning teaching process, including in English learning. It cannot be seen with only one eye. It should be taught as soon as possible. One strategy which can be done to do it is by representing the tolerance values in learning materials including EFL textbook. By covering the values, it is lexpected to be able to help students boost their valuable knowledge about tolerance values that can be applied in their real life to respect the differences of norms, cultures, beliefs, etc, avoid and reconcile conflicts, accept unwanted situation, and so on. (Levina, Lukmanova, Romanovskaya, \& Shutova, 2016) stated that infusing tolerance values into English language learning is very important to help students understand to accept and respect individual culture; gender, race, disability, religion, and so on. The explanation shows that tolerance values play an important role in learning teaching process including English learning teaching process to grow students' responsibility, love and care, sympathy and empathy, and so on. So, it must be supported by many factors in the process; teachers, learning materials, and so on. 


\section{Tolerance values representation in English Learning materials}

English learning material is not only a tool to help students communicate in English in their activities but also it must be able to facilitate the students to improve their lives values. One the values is tolerance. By planting and growing tolerance, students are expected to have guidelines to live together in their community. (Tomar, 2014)expressed that learning material should be selected properly in order facilitate students to boost knowledge and life-values; moral, tolerance, justice and so on. Moreover, (Moss Ed., 2013) stated that learning materials must be able to improve students living values. For example, to teach students to be a peace maker, a teacher can give his students a text about bullying and discuss it by giving possible factors that may lead the problem. Then, discuss appropriate method to solve the problem. The discussions above really shows that tolerance values cannot be separated in learning materials including English learning materials.

\section{EFL Electronic Textbooks.}

Internet connection has become an inseparable part in modern life. It has changed every single human activity, including in learning teaching process. A teachers and students tend to use the connection for many purposes including providing learning material. Several years ago, students brought many printed textbooks to school and it seemed not practical. So, they change their habit from using printed learning materials to electronic textbooks. (Knight, 2015) stated that electronic textbook is a learning in form of textbook which is provided by certain organization, institution, or government in the form of digital format and it can be accessed by internet connection. Moreover, (Kouis \& Konstantinou, 2014)mentioned some advantages of electronic textbook; 1. Electronic textbook is easy to be updated or renewed, 2. Electronic textbook can be accessed every where. Because of the practical and advantages of electronic textbook, many institutions including Indonesian ministry for education and culture (Kemdikbud) provides EFL electronic textbooks to help students in learning teaching process.

\section{METHOD}

This research is intended to analyze the representation of tolerance values in the first grade of Junior High School Indonesian EFL textbooks "Contextual Teaching and Learning: Bahasa Inggris" published by Indonesian ministry for education and culture (Kemdikbud). The reason to choose the textbook is because English become a compulsory subject for the first time in Indonesian school. Qualitative content analysis is employed to analyze the contents in the textbooks. (Elo \& Kyngäs, 2008) stated that qualitative content analysis is a method which is used to analyze written and spoken document and visual communication. Moreover, (Hossein Hashemnezhad, 2015) defined qualitative content analysis is a method for subjective 
interpretation the meaning of text data. To get the data, the researcher dis several steps; identifying textbook elements that contain tolerance values from texts, illustrations, instructions and exercises. Categorizing the values into four categories; peace maker human rights, democracy, and religious values into a table, and counting the dominant value represented in the textbook.

\section{FINDINGS AND DISCUSSION}

After reading and analyzing the textbook as the data, researcher found that the way of the textbooks represents all categories of tolerance values by implementing the values in the discussion of conversation, illustrations, instructions, and exercises. Besides, the researcher also found 72 items of tolerance values covered in the textbook The peace maker is the dominant tolerance value in the textbook with 24 items or $33,3 \%$. The cultural diversity is in the second place with 19 items or 26,3\%. Meanwhile, democracy, and religious values are in the third and fourth place with 15 or $20,8 \%$ and 14 items or 19,4\%. All items of tolerance values are put in the table to help the researcher analyse, categorize, and count the items of tolerance value. See the table below to give an illustration how the researcher analyzed the textbook elements. However, the researcher only puts some items of tolerance values as a sample of analysis. See table 1.

Table 1 Sample of Table Analysis

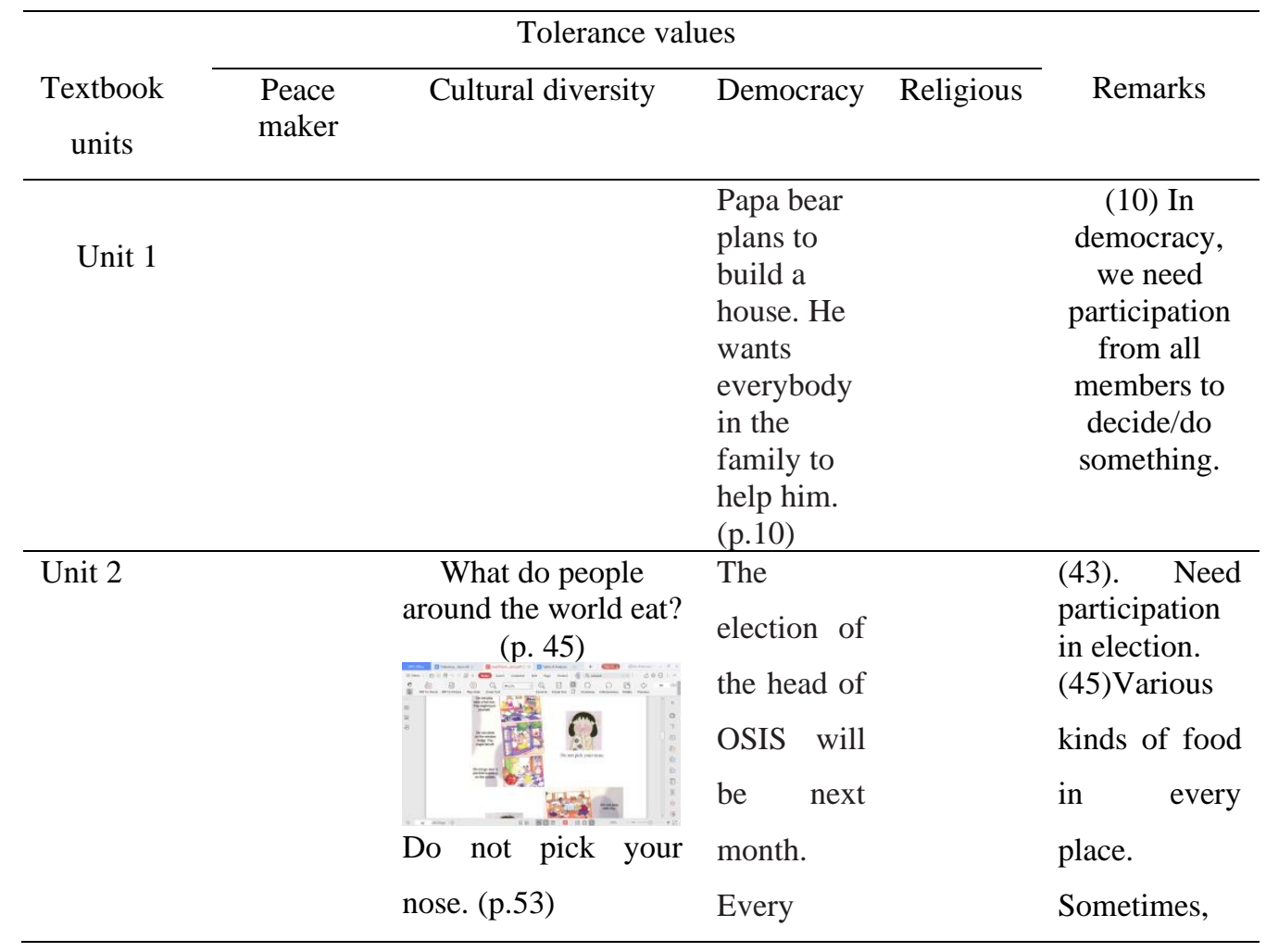




\begin{tabular}{|c|c|c|c|c|}
\hline & & $\begin{array}{l}\text { student } \\
\text { should... } \\
\text { (p.43) }\end{array}$ & & $\begin{array}{l}\text { someone's } \\
\text { daily food } \\
\text { looks weird. } \\
\text { But we may } \\
\text { not insult it } \\
\text { because it can } \\
\text { cause } \\
\text { problem. } \\
\text { (53) polite } \\
\text { action in } \\
\text { certain place. } \\
\text { We have to } \\
\text { respect the } \\
\text { value. }\end{array}$ \\
\hline Unit 3 & $\begin{array}{l}\text { A : I } \\
\text { apologize. } \\
\text { I broke } \\
\text { your } \\
\text { crystal } \\
\text { vase. } \\
\text { B : No } \\
\text { problem. } \\
\text { A: That's } \\
\text { very nice } \\
\text { of you. } \\
\text { But, let me } \\
\text { pay for the } \\
\text { damage. } \\
\text { (80) }\end{array}$ & & & $\begin{array}{l}\text { (80) Every } \\
\text { body will } \\
\text { make } \\
\text { mistakes in } \\
\text { his life. So, he } \\
\text { should find to } \\
\text { solve the } \\
\text { situation; } \\
\text { apologizing, } \\
\text { showing } \\
\text { responsibility, } \\
\text { etc. Unless he } \\
\text { will make a } \\
\text { conflict. }\end{array}$ \\
\hline & & & $\begin{array}{l}\text { Banu, } \\
\text { could } \\
\text { you take } \\
\text { me } \\
\text { home? I } \\
\text { have a } \\
\text { flat tire. } \\
\text { Banu : } \\
\text { Certainly }\end{array}$ & $\begin{array}{l}\text { Show } \\
\text { kindness to } \\
\text { everyone } \\
\text { without } \\
\text { thinking who } \\
\text { really he is. }\end{array}$ \\
\hline
\end{tabular}

Based on the findings and analysis above, we may infer that Indonesian EFL electronic textbook for the first grade of Junior High School "Contextual Teaching and Learning: Bahasa Inggris" covers all categories of tolerance values; peace maker, cultural diversity, democracy, and religious values. However, what comes to the researcher's concern is that the textbook lacks 
to give comprehensive samplesand discussions about the values. For example: conversation on page 80 that represents the peace maker value" A: I apologize. I broke your crystal vase. B:No problem. A: That's very nice of you. But, let me pay for the damage." The textbook only puts the conversation as one element of learning materials without giving deeper explanation and discussion of the message consisted in the conversation. The conversation has a great potential to be discussed as a peace maker value. The textbook should have given more discussions to explore and grow students understanding by giving students samples, exercises, etc. For example: the textbook should give some questions that relates to the value "Why do we need to apologize when we make a mistake?”, “What will happen if we do not apologize when we make a mistake?", “What are you going to do if your friend shows his apologizing?” , "Is there any potential conflict if we do not apologize for our mistakes? Those questions can be addressed to the students to give the more comprehensive understanding about tolerance value of a peace maker. As stated by (Datzberger, 2017) that education, including in EFL learning materials selection play an important role to build students awareness to make peacefulness in the world. This means that learning materials must contain samples, discussion, and so on that can reflect peace maker.

For cultural diversity value, the textbook can explore the value and give students real-life samples like the condition in Indonesia that consists of thousand of islands, cultures, languages, etc. (Sharma, 2005) stated that cultural diversity needs to be explored in learning-teaching process to give students knowledge to avoid discrimination, social conflict, etc. The item that represents cultural diversity in the textbook is on page 45 at the sentence "What do people around the world eat?". But, the textbook only writes the sentence as title one of the book chapters without exploring the message of the sentence. No questions or exercises are given to help students get the points of cultural diversity about food. The textbook should have given some questions to boost students understanding various food consumed in certain place. For example "What are you going to do if visit certain place in Indonesia in which the people eat food that you do not like?", “ Is any potential conflict caused by different food consumption?”. Another example of cultural diversity item in the text book is on page 53. On the page, the book gives an illustration with sentence "do not pick your nose". The sentence can be discussed as cultural diversity value because the sentence has potential value that adopted in certain place.

The next tolerance value is democracy value. Understanding and applying the values of democracy in real life is very important to avoid conflict and appreciate people's rights. On page 45, the textbook puts a conversation about the election of head of students' council(OSIS).However, there is no a question or exercise that leads students to get deeper 
understanding about tolerance in democracy. The textbook should have put some questions or exercises "What are you going to if your best friend votes different candidate for captain of students' council?". This is a sample question that can be used to grow students understanding about democracy. It is along with the statement of (Alemán \& Kim, 2015) that learning-teaching process must give contribution to foster students social democracy. That is why learning materials must be selected to help students boost their democracy value.

The last, the textbook also covers the religious value. The values is represented by putting a sentence, instruction, an so on in the book that contains moral value, kindness, religious activities. For example: a conversation on page 71 " Sani: Banu, could you take me home? Banu: Certainly." The conversation covers religious because it contains kindness of how to help other people without thinking who really they are. The books should give another question or exercise to give students more comprehension about religious value. For example: "What are you going to do if your neighbour needs your help to decorate his house for religious events?". This value must be explored extensively to help students to do kindness based on religious beliefs, (Firdaus, 2018). By giving students comprehensive understanding about religious tolerance, it is expected that they will help self awareness to help, respect,and love other people.

\section{CONCLUSION}

The textbook already covers all categories of tolerance values; peace maker, cultural diversity, democracy, and religious study with with variant domination. It shows that the textbook is aware to prepare students with valuable knowledge for their life. The peace maker value is the dominant tolerance value covered in the textbook with 24 items or 33,3\%. It means that the textbook really concerns on how to avoid conflict in human's life or the textbook wants to teach people how to live together in harmony. The second, third, and fourth position are the values of cultural diversity, democracy, and religious value. However, the textbook needs to give deeper exploration and discuss for every single tolerance value stated in the textbook by giving questions, case study, discussions, etc.

\section{REFERENCES}

Abdul Rahman, N. F., \& Mohd Khambali, K. (2013). Religious Tolerance in Malaysia: Problems and Challenges. International Journal of Islamic Thought, 3(1), 81-91. https://doi.org/10.24035/ijit.03.2013.007

Alemán, E., \& Kim, Y. (2015). The democratizing effect of education. Research and Politics, 2(4). https://doi.org/10.1177/2053168015613360

Datzberger, S. (2017). Peacebuilding through non-formal education programmes: a case study from Karamoja, Uganda. International Peacekeeping, 24(2), 326-349. 
https://doi.org/10.1080/13533312.2016.1214073

Dobbernack, J., \& Modood, T. (2011). Tolerance and Cultural Diversity in Europe: Theoretical perspectives and contemporary developments. 1-38. Retrieved from http://cadmus.eui.eu/handle/1814/19790\%0Awww.eui.eu/RSCAS/\%0AAvailable\%0Aw ww.accept-pluralism.eu

Elo, S., \& Kyngäs, H. (2008). The qualitative content analysis process. Journal of Advanced Nursing, 62(1), 107-115. https://doi.org/10.1111/j.1365-2648.2007.04569.x

Firdaus, E. (2018). The Learning of Religious Tolerance among Students in Indonesia from the Perspective of Critical Study. IOP Conference Series: Earth and Environmental Science, 145(1). https://doi.org/10.1088/1755-1315/145/1/012032

Giuliani, A., Fernandez, M., Farinelli, M., Baratto, L., Capra, R., Rovetta, G., ... Calzà, L. (2004). Very low level laser therapy attenuates edema and pain in experimental models. International Journal of Tissue Reactions, 26(1-2), 29-37.

Hameiri, B., Bar-Tal, D., \& Halperin, E. (2014). Challenges for Peacemakers: How to Overcome Socio-Psychological Barriers. Policy Insights from the Behavioral and Brain Sciences, 1(1), 164-171. https://doi.org/10.1177/2372732214548428

Hossein Hashemnezhad. (2015). Qualitative Content Analysis Research: A Review Article. Journal of ELT and Applied Linguistics (JELTAL), 3(1), 54-62.

Knight, B. A. (2015). Teachers' use of textbooks in the digital age. Cogent Education, 2(1). https://doi.org/10.1080/2331186X.2015.1015812

Kouis, D., \& Konstantinou, N. (2014). Electronic textbooks advantages and challenges for the hellenic higher education and publishing community. Library Review, 63(6-7), 531-543. https://doi.org/10.1108/LR-06-2014-0074

Kurniawan, K. N. (2018). Tolerance education in the hidden curriculum : A case study on Indonesian public school. MASYARAKAT Jurnal Sosiologi, 23(1), 1-30. https://doi.org/10.7454/M

Leo, J. de. (2010). Education for Intercultural Understanding. Retrieved from https://unesdoc.unesco.org/ark:/48223/pf0000189051

Levina, L., Lukmanova, O., Romanovskaya, L., \& Shutova, T. (2016). Teaching Tolerance in the English Language Classroom. Procedia - Social and Behavioral Sciences, 236(December 2015), 277-282. https://doi.org/10.1016/j.sbspro.2016.12.029

Moss Ed., B. (2013). Teaching Tolerance: Resources for Students and Teachers. Voices from the Middle, 20(3), 52-56.

Sharma, S. (2005). Multicultural Education: Teachers Perceptions And Preparation. Journal of 
College Teaching \& Learning (TLC), 2(5), 139-146. https://doi.org/10.19030/tlc.v2i5.1825

Suardi Wekke, 2017. (2017). Religious Education and Tolerance : Learning Process in High School of RELIGIOUS EDUCATION AND TOLERANCE : LEARNING PROCESS IN HIGH SCHOOL OF. Journal Civic Education, 3,Nomor 3(January), 137-141.

Tomar, B. (2014). Axiology in Teacher Education: Implementation and Challenges. IOSR Journal of Research \& Method in Education (IOSRJRME), 4(2), 51-54. https://doi.org/10.9790/7388-04235154

Yusuf, H. O. (2013). Promoting Peaceful Co-Existence and Religious Tolerance through Supplementary Readers and Reading Comprehension Passages in Basic Education Curriculum. International Journal of Humanities and Social Science, 3(8), 224-232. 